\title{
Effects of dietary extruded linseed (Linum usitatissimum L.) on performance and meat quality in Podolian young bulls
}

\author{
S. Tarricone ${ }^{1}$, M.A. Colonna ${ }^{1 \#}$, F. Giannico ${ }^{1}$, A.M. Facciolongo ${ }^{2}$, A. Caputi Jambrenghi $^{1}$ \& \\ M. Ragni ${ }^{1}$ \\ ${ }^{1}$ Department of Agricultural and Environmental Science, University of Bari Aldo Moro, Via G. Amendola 165/A, 70126, \\ Bari, Italy \\ ${ }^{2}$ Institute of Biosciences and BioResources, National Research Council, Via G. Amendola 165/A, 70126, Bari, Italy
}

(Submitted 30 May 2019; Accepted 21 August 2019; First published online 17 September 2019)

\author{
Copyright resides with the authors in terms of the Creative Commons Attribution 4.0 South African License. \\ See: http://creativecommons.org/licenses/by/4.0/za \\ Condition of use: The user may copy, distribute, transmit and adapt the work, but must recognize the authors and the South African \\ Journal of Animal Science.
}

\begin{abstract}
This study compared effects of a diet containing 3\% extruded linseed (EL) (Linum usitatissimum L.) with a control diet (C) on growth, carcass traits, and meat quality in young Podolian bulls. After 208 days on feed, the bulls were slaughtered at 18 months of age. Samples of Longissimus lumborum (LI) were analysed to assess their physical and chemical parameters and intramuscular fatty acid composition. Average daily gain, feed intake and feed efficiency were not affected by treatments. Bulls fed EL $(n=6)$ had significantly greater final $(612 \mathrm{~kg}$ versus $593 \mathrm{~kg})$ and slaughter weights $(583 \mathrm{~kg}$ versus $563 \mathrm{~kg})$ than those fed $\mathrm{C}(\mathrm{n}=6)$. Compared with C, EL significantly increased percentages of lean from the pelvic limb (71.9\% versus $69.3 \%)$ and of bone from the lumbar region (30.0 versus $27.1 \%)$. Meat $\mathrm{pH}$ recorded at slaughter was significantly greater for $C$ than EL (6.7 versus 6.4). Diet did not affect meat colour, chemical composition and shear force of either the raw or cooked meat. Total amounts of saturated, monounsaturated and polyunsaturated fatty acids were not influenced by the diets. Concentrations of linoleic acid (C18:2 n-6) (3.30 versus 4.08) and total $n-6$ fatty acids (3.83 versus 4.73 ) were reduced by EL, while EL significantly enhanced linolenic acid (C18:3 n-3) (0.45 vs 0.20 ) and total $n-3$ fatty acids (1.64 versus 1.18$)$ in the meat compared with C. Thus, dietary supplementation with $3 \% \mathrm{EL}$ improved the amount of $\mathrm{n}-3$ fatty acids in the meat from young Podolian bulls without affecting their performance.
\end{abstract}

Keywords: carcass traits, fatty acids, feed efficiency, growth, meat colour

\#Corresponding author: mariaantonietta.colonna@uniba.it

\section{Introduction}

Podolian cattle are an autochthonous breed, which belongs to the Hungarian grey steppe cattle group. They are reared primarily in southern Italy and are well adapted to the environment, displaying longevity and disease resistance (Braghieri et al., 2009). In rearing systems typical of southern Italy, females are used to produce high-quality milk and derivatives (Cosentino et al., 2018) while calves are slaughtered after weaning, at about 6-8 months old, or are fed a finishing diet in loose house conditions (Marino et al., 2006; Vicenti et al., 2009; Bragaglio et al., 2018). The use of local breeds and low input production systems is being ever more appreciated by consumers who are rediscovering traditional food products. Red meats have often been associated with cardiovascular disease owing to their high saturated fatty acid (SFA) content (McAfee et al., 2010; Salter, 2013). Myristic (C14:0), palmitic (C16:0), and stearic (C18:0) acids are the main contributors to increased blood cholesterol levels and atherogenic and thrombogenic indices of meat (Ulbricht \& Southgate, 1991). The consumption of lean meat that is low in saturated fat and high monounsaturated fatty acids (MUFA) and polyunsaturated fatty acids (PUFA) is recommended (Lunn \& Theobald, 2006; Scollan et al., 2014) to benefit human health by preventing cancer, atherosclerosis and coronary heart disease (CHD), The World Health Organization (WHO) (2003) advises that there should be an optimal balance between intake of n-6 PUFAs and n-3 PUFAs, that is, $5-8 \%$ and $1-2 \%$ of daily energy intake, respectively. Several health problems have been observed when the $n-6 / n-3$ ratio is too high, with excessive consumption of $n-6$ FAs being associated with autoimmune and cardiovascular disease (Simopoulos, 2004). Therefore, alternative animal feeding strategies need to be developed that would 
increase the PUFA content of meat. However, accomplishing this enrichment in ruminants is challenging owing to the biohydrogenation of fatty acids, which occurs in the rumen (Bessa et al., 2000; Lunn \& Theobald, 2006). In the last decade several attempts have been made to increase the PUFA content in meat from ruminant livestock, including dietary supplementation with linseed and linseed oil in lambs (Giannico et al., 2009; Colonna et al., 2011; Toteda et al., 2011; Facciolongo et al., 2018), in kids (Rotondi et al., 2018), and in steers (Juárez et al., 2012; Ragni et al., 2014; Utama et al., 2018). Heat extrusion of oil from linseed has been shown to be a successful way of protecting the seeds from ruminal degradation (Mustafa et al., 2003; Gonthier et al., 2004; Raes et al., 2004). Thus, this study aimed to evaluate the effect of dietary supplementation with extruded linseed on the performance and meat quality in young Podolian bulls.

\section{Materials and Methods}

All procedures involving animals were performed according to the guidelines of the Italian Government (Directive 91/629/EEC, received in Italy by D.L. 533/92 and modified by D.L. 331/98).

The trial was carried out from January to July 2018 on a farm located in Irsina (MT) (Basilicata region, southern Italy, $40^{\circ} 78^{\prime} \mathrm{N}$ latitude, $16^{\circ} 29^{\prime} \mathrm{E}$ longitude). Twelve Podolian calves were left to graze with their dams until they were approximately 11 months ( \pm 10 days) old. The calves were stratified by weight and age and assigned to one of the two iso-caloric and iso-nitrogenous dietary treatments, namely a control diet (C) and a diet containing 3\% EL (as fed basis). The animals were gradually adapted to the experimental diets for two weeks. The rations (Table 1) were pelleted and balanced for intestinal digestible protein nitrogen (PDIN) and intestinal digestible protein energy (PDIE) to meet the calves' nutritional requirements (INRA, 1988; 1989). The calves were housed individually in pens $\left(4 \mathrm{~m}^{2}\right)$, each of which was equipped with a trough, manger and outdoor paddock without grass.

Feed was offered daily each morning at a rate of $110 \%$ of ad libitum intake, calculated by weekly weighing of refused feed. All animals had free access to water and received ad libitum durum wheat straw (Triticum durum L.). Feed samples were taken monthly and stored at $-20^{\circ} \mathrm{C}$ until analysis. Every day, after feeding, the remaining straw and pelleted feeds were weighed to determine the daily feed intake of each animal. Individual bodyweights were recorded at the beginning of the trial (day 0 ) and after 208 days on feed (before slaughtering). Average daily gain (ADG), average daily feed intake (ADFI) and feed conversion ratio (FCR) ( $\mathrm{kg}$ food ingested daily/kg daily body growth) were calculated from these measurements.

Samples of each pelleted feed were ground in a hammer mill with a 1-mm screen and analysed in triplicate using the AOAC (2004) procedures, namely dry matter (DM) (method 934.01), ether extract (EE) (method 920.39), ash (method 942.05), crude protein (CP) (method 954.01), crude fibre (CF) (method 945.18), acid detergent fibre (ADF), acid detergent lignin (ADL) (method 973.18) and amylase-treated neutral detergent fibre (NDF) (method 2002.04). Starch was also determined by an AOAC procedure (2004) (method 996.11). The fatty acid composition of samples from each concentrate mixture was determined using the method described below for meat FA profile. The characterization of the diets is shown in Table 1.

At the end of the trial, the young bulls were transported to the slaughterhouse, where they were weighed and slaughtered by exsanguination (according to veterinary police rules (D.P.R. 320/54)) after fasting for 12 hours with free access to water. After slaughter, the hot carcass, full skin, head, offal parts and shins were weighed. The weight of the digestive contents (full and empty gastro-intestinal tract) was used to calculate the net cold dressing percentage (carcass weight after chilling/empty bodyweight). The carcasses were divided into two half sides. The right side was weighed immediately and after refrigeration for 24 hours at $4{ }^{\circ} \mathrm{C}$. Two sample cuts, the lumbar region and pelvic limb, were separated and dissected into their tissue components, namely lean, fat and bone. The $\mathrm{pH}$ was measured on the $\mathrm{LI}$ of the right half-carcass at the time of slaughter $\left(\mathrm{pH}_{0}\right)$ and after 24 hours of refrigeration at $4{ }^{\circ} \mathrm{C}\left(\mathrm{pH}_{24}\right)$, using a portable instrument (Hanna Instruments HI 9025, Woonsocket, RI) with an electrode (FC 230C, Hanna Instruments) and performing twopoint calibration (pH 7.01 and 4.01).

Samples of the $L /$ muscle were taken to evaluate meat quality characteristics. Meat colour $\left(L^{*}\right.$ lightness; $a^{\star}$ redness; $b^{*}$ yellowness) was assessed using a HunterLab MiniScanTM XE spectrophotometer (Model 4500/L, 45/0 LAV, $3.20 \mathrm{~cm}$ diameter aperture, $10^{\circ}$ standard observer, focusing at $25 \mathrm{~mm}$, illuminant D65/10, Hunter Associates Laboratory, Inc, Reston, Virginia, USA) by taking three readings for each sample. The instrument was normalized to a standard white tile, which was supplied with the instrument, before the analysis was performed $(Y=92.8 ; x=0.3162$, and $y=0.3322)$. The reflectance measurements were performed after the sample had been oxygenated in air for at least 30 minutes to allow the measurements to become stable (Šicklep \& Čandek-Potokar, 2007). Meat tenderness was assessed on raw and cooked $L I$ samples with the Warner Bratzler shear (WBS) force system using an Instron 5544 universal testing machine (Instron Corp., Canton, MA, USA). The samples were cylindrical and $2.54 \mathrm{~cm}$ in diameter, assessed in triplicate, and sheared perpendicular to the muscle fibre direction (load cell $50 \mathrm{~kg}$, shearing speed 200 $\mathrm{mm} / \mathrm{min}$ ). Peak force was expressed as $\mathrm{kg} / \mathrm{cm}^{2}$. 
Table 1 Feed ingredients ( $\mathrm{g} / \mathrm{kg}$ as fed basis), chemical (\% dry matter basis) and fatty acid composition (\% methyl esters) of the treatment diets

\begin{tabular}{|c|c|c|}
\hline & \multicolumn{2}{|c|}{ Diets } \\
\hline & Control & Extruded linseed \\
\hline \multicolumn{3}{|l|}{ Ingredient composition (g/kg as-fed basis) } \\
\hline Field beans & 310 & 310 \\
\hline Ground barley & 310 & 310 \\
\hline Soybean hulls & 310 & 300 \\
\hline Extruded soy ( $36.7 \%$ crude protein) & 20 & - \\
\hline Extruded linseed (20.0\% crude protein) & - & 30 \\
\hline Vitamin mineral premix & 50 & 50 \\
\hline \multicolumn{3}{|l|}{ Chemical composition $^{1}$ (\% DM basis) } \\
\hline Metabolizable energy (MJ/kg DM) & 11.87 & 12.01 \\
\hline Moisture & 12.50 & 12.50 \\
\hline Crude protein & 13.66 & 13.56 \\
\hline Ether extract & 2.34 & 2.95 \\
\hline Crude fibre & 5.86 & 5.73 \\
\hline Ash & 5.58 & 5.51 \\
\hline Starch & 40.00 & 39.94 \\
\hline NDF & 12.29 & 12.19 \\
\hline ADF & 7.20 & 7.02 \\
\hline ADL & 0.95 & 1.30 \\
\hline PDIN (g/kg DM) & 115.72 & 125.35 \\
\hline PDIE (g/kg DM) & 116.98 & 118.05 \\
\hline Meat forage units (n/kg DM) & 1.06 & 1.07 \\
\hline \multicolumn{3}{|c|}{ Fatty acid composition (\% fatty acid methyl esters) } \\
\hline C14:0 (myristic acid) & 0.29 & 0.21 \\
\hline C16:0 (palmitic acid) & 15.08 & 10.51 \\
\hline C18:0 (stearic acid) & 1.90 & 2.33 \\
\hline C16:1 (palmitoleic acid) & 0.12 & 0.17 \\
\hline C18:1n-9 (oleic acid) & 25.60 & 21.92 \\
\hline C18:2n-6 (linoleic acid) & 36.63 & 30.24 \\
\hline C18:3n-3 ( $\alpha$-linolenic acid) & 1.94 & 11.58 \\
\hline
\end{tabular}

${ }^{1}$ DM: dry matter, NDF: neutral detergent fibre; ADF: acid detergent fibre; ADL: acid detergent lignin; PDIN: protein digested in the small intestine allowed by the nitrogen; PDIE: protein digested in the small intestine allowed by the energy.

To determine the percentage of loss during cooking, homogeneous samples (approximately $5 \mathrm{~cm}$ thick) were cut from the $\mathrm{LI}$ muscle and weighed before and after cooking in a ventilated electric oven at 165 ${ }^{\circ} \mathrm{C}$ until an internal temperature of $75^{\circ} \mathrm{C}$ was reached in the centre of the sample (ASPA, 1996), as recorded by a thermocouple (Hanna Instruments).

Chemical analysis and FA profile were performed on raw meat of the $L /$ muscle, using $250 \mathrm{~g}$ samples, devoid of external fat, epimysium and parts in which metmyoglobin was visible. AOAC (1995) procedures were used to assess moisture, crude fat, protein and ash. Total lipids were extracted from the homogenized $\mathrm{L} /$ samples $(100 \mathrm{~g})$ according to the chloroform/methanol method described by Folch et al. (1957). FAs were methylated using $\mathrm{BF}_{3}-$ methanol solution $(12 \% \mathrm{v} / \mathrm{v})$ (Christie, 1982). The FA profile was assessed with a Chrompack CP 9000 gas chromatograph, with a silicate glass capillary column (70\% cyanopropyl 
polysilphenylene-siloxane BPX 70 of SGE Analytical Science, length $50 \mathrm{~m}$, internal diameter $0.22 \mathrm{~mm}$, film thickness $0.25 \mu \mathrm{m}$ ). The temperature programme was $135^{\circ} \mathrm{C}$ for $7 \mathrm{~min}$, followed by increases of $4{ }^{\circ} \mathrm{C}$ per minute to $210{ }^{\circ} \mathrm{C}$. The food risk factors of meat were determined by calculating the atherogenic (Al) and thrombogenic (TI) indices from the fatty acid composition according to Ulbricht \& Southgate (1991).

The data were analysed with a one-way ANOVA that was conducted using the GLM procedure of SAS $^{\circledR}$ (SAS Institute Inc., Cary, North Carolina, USA). Least squares means and pooled standard errors of the difference between the means (SED) are reported. Means were compared using student's $t$-test.

\section{Results and Discussion}

The bulls that were fed the extruded linseed diet had a greater final bodyweight than the control group $(P<0.05)$, although no significant difference between dietary treatments was found for the average daily feed intake or for the average daily gain (Table 2). Other studies carried out on Podolian cattle have reported comparable ADG (Marino et al., 2006; Bragaglio et al., 2018), while the growth rates observed in this trial were less than those reported by Ragni et al. (2014).

Table 2 Bodyweight, average daily gain, average daily feed intake, and feed conversion ratio for 18-monthold Podolian bulls

\begin{tabular}{lccc}
\hline & \multicolumn{2}{c}{ Diets } & SE difference \\
\cline { 2 - 3 } & Control & Extruded linseed & \\
\hline Initial bodyweight $(\mathrm{kg})$ & 368.7 & 378.3 & 19.1 \\
Final bodyweight $(\mathrm{kg})$ & $593.3^{\mathrm{b}}$ & $612.8^{\mathrm{a}}$ & 2.60 \\
Average daily gain $(\mathrm{kg} / \mathrm{d})$ & 1.08 & 1.12 & 0.09 \\
Average daily feed intake $(\mathrm{kg} / \mathrm{d})$ & 8.40 & 8.50 & 1.98 \\
Feed conversion ratio $(\mathrm{kg} / \mathrm{kg})$ & 7.77 & 7.59 & 1.02 \\
\hline
\end{tabular}

${ }^{1}$ Standard error of the difference between means, $d f$ : degrees of freedom

${ }^{a}$, Row means differ significantly at $P<0.05$

Bulls fed EL were significantly heavier at slaughter than those fed C (Table 3). They were also heavier at slaughter than those used in other studies on the same breed (Marino et al., 2006; Scerra et al., 2014), probably because of the longer duration of the feeding period in this study. Also the gastro-intestinal apparatus (internal organs) weight was greater $(P<0.05)$ for the EL-fed bulls, which may have levelled the differences in hot carcass weights between diets. No differences between treatments were detected for the other components of the whole carcass.

Data from dissection of the pelvic limb and lumbar region are shown in Table 4. Bulls whose diet was supplemented with EL had a greater $(P<0.05)$ percentage of lean in the pelvic limb. Ragni et al. (2014) made a similar observation from young Podolian bulls fed a flaxseed-based diet. However, different from Ragni et al. (2014), the percentage of bone from the lumbar region was greater for bulls that were fed EL than those fed the control diet. 
Table 3 Weights of components of the whole carcass from 18-month old Podolian bulls $(\mathrm{kg})$

\begin{tabular}{|c|c|c|c|}
\hline & \multicolumn{2}{|c|}{ Diets } & \multirow{2}{*}{ SE difference ${ }^{1}$} \\
\hline & Control & Extruded linseed & \\
\hline Slaughtering bodyweight & $563.66^{b}$ & $583.34^{a}$ & 2.60 \\
\hline Gastro-intestinal apparatus & $42.22^{b}$ & $52.47^{\mathrm{a}}$ & 2.68 \\
\hline Hot half carcass weight & 170.83 & 181.62 & 10.72 \\
\hline Chilled half carcass weight & 167.83 & 177.60 & 10.74 \\
\hline Skin & 54.38 & 55.08 & 2.23 \\
\hline Head & 26.12 & 28.30 & 1.32 \\
\hline Offal parts & 17.78 & 19.83 & 1.76 \\
\hline Shins & 2.18 & 2.39 & 0.09 \\
\hline Pelvic limb & 40.39 & 39.68 & 2.65 \\
\hline Lumbar region & 9.83 & 9.76 & 1.26 \\
\hline Perirenal fat & 2.71 & 3.30 & 0.54 \\
\hline
\end{tabular}

${ }^{1}$ Standard error of the difference between means

${ }^{\mathrm{a}, \mathrm{b}}$ Row means differ significantly at $P<0.05$

Table 4 Dissection data of pelvic limb and lumbar region of young Podolian bulls

\begin{tabular}{lccc}
\hline & \multicolumn{2}{c}{ Diets } & SE difference ${ }^{1}$ \\
\cline { 2 - 4 } & Control & Extruded linseed & 2.65 \\
Pelvic limb (kg) & 40.39 & 39.68 & 7.13 \\
Lean (\% on weight) & $69.32^{\mathrm{b}}$ & $71.85^{\mathrm{a}}$ & 1.54 \\
Fat (\% on weight) & 12.42 & 12.20 & 1.74 \\
Bone (\% on weight) & 18.26 & 15.95 & 1.25 \\
Lumbar region (kg) & 9.83 & 9.76 & 6.13 \\
Lean (\% on weight) & 64.04 & 62.04 & 1.45 \\
Fat (\% on weight) & 8.82 & 7.92 & 2.25 \\
Bone (\% on weight) & $27.14^{\mathrm{b}}$ & $30.04^{\mathrm{a}}$ & \\
\hline
\end{tabular}

${ }^{1}$ Standard error of difference between means

a, b Row means differ significantly at $P<0.05$

Physical and chemical features of meat from the $\mathrm{LI}$ muscle are shown in Table 5. The $\mathrm{pH}$ value recorded immediately after slaughter $\left(\mathrm{pH}_{0}\right)$ was greater $(P<0.05)$ in the control group than for the bulls that were fed EL. However, after refrigeration for 24 hours, no difference in $\mathrm{pH}$ was detected between treatments. This is in agreement with the findings of Corazzin et al. (2012). In contrast, Marino et al. (2006) and Mapiye et al. (2013) did not observe dietary effects on the $\mathrm{pH}_{0}$ while they recorded significant differences after refrigeration for 24 hours $\left(\mathrm{pH}_{24}\right)$. Ragni et al. (2014) did not observe significant dietary effects in Podolian bulls on $\mathrm{pH}$ at slaughter or after chilling.

Dietary treatment did not affect the colorimetric response of $L /$ meat samples (Table 5). However, all the colour measures were slightly less for bulls fed EL than for those fed C. Similar results were reported by Mapiye et al. (2013) and Della Rosa et al. (2018), while Ragni et al. (2014) found a significantly greater L* value in bulls fed extruded linseed compared with a soybean-based diet. In this study, the observed $L^{*}$ values were comparable with those reported by Juárez et al. (2012) in steers fed flaxseed with or without vitamin E supplementation.

No significant differences were observed between treatments for Warner-Bratzler shear force (WBS) of raw and cooked meat (Table 5), in agreement with other studies (Corrazin et al., 2012; Ragni et al., 2014; Della Rosa et al., 2018). The control diet had a slight numerically greater cooking loss, while findings 
reported by other authors indicated no effect of dietary treatment on cooking loss (Razminowicz et al., 2007; Corrazin et al., 2012).

The chemical composition of meat (Table 5) was similar between dietary treatments and in agreement with previous results for Podolian cattle (Marino et al., 2006; Ragni et al., 2014; Scerra et al., 2014).

Table 5 Physical and chemical features of meat from the Longissimus lumborum muscle of 18-month-old Podolian bulls

\begin{tabular}{lrrr}
\hline & \multicolumn{2}{c}{ Diets } & SE difference ${ }^{1}$ \\
\cline { 2 - 3 } & \multicolumn{1}{c}{ Control } & Extruded Linseed & \\
\hline $\mathrm{pH}_{0}$ & $6.70^{\mathrm{a}}$ & $6.35^{\mathrm{b}}$ & 0.18 \\
$\mathrm{pH}_{24}$ & 5.52 & 5.50 & 0.24 \\
$\mathrm{~L}^{\star^{2}}$ & 37.06 & 36.73 & 1.34 \\
$\mathrm{a}^{\star^{3}}$ & 16.79 & 16.46 & 3.34 \\
$\mathrm{~b}^{\star^{4}}$ & 13.81 & 12.62 & 1.57 \\
WBS $^{5}$ raw meat $\left(\mathrm{kg} / \mathrm{cm}^{2}\right)$ & 2.62 & 1.80 & 0.69 \\
WBS $^{5}$ cooked meat $\left(\mathrm{kg} / \mathrm{cm}^{2}\right)$ & 4.17 & 5.31 & 1.37 \\
Cooking loss $(\%)_{\text {Moisture (\%) }}$ & 33.64 & 31.37 & 4.77 \\
Protein (\%) & 72.65 & 72.35 & 1.05 \\
Fat (\%) & 21.34 & 22.27 & 0.76 \\
Ash (\%) & 3.34 & 2.82 & 0.89 \\
& 1.15 & 1.18 & 0.01 \\
\hline
\end{tabular}

\footnotetext{
${ }^{1}$ Standard error of the difference between means

${ }^{2} \mathrm{~L}$ : lightness

${ }^{3}$ a: redness

${ }^{4} \mathrm{~b}$ : yellowness

${ }^{5}$ WBS: Warner-Bratzler shear force

A, B Row means differ significantly at $P<0.01$

a, b Row means differ significantly at $P<0.05$
}

The fatty acid profile of the meat is shown in Table 6. Diet did not affect the percentage of saturated fatty acids (SFA). Similar to results from a study on Charolais cattle (Ragni et al., 2018), C16:0 (palmitic acid) was the most abundant SFA, followed by C18:0 (stearic acid). These results are in general agreement with those from young Podolian bulls (Vicenti et al., 2009). The MUFA concentration of meat did not differ between treatments. Previous studies with lambs (Colonna et al., 2011) and beef cattle (Vicenti et al., 2009; Ragni et al., 2018) found similar results. Among the MUFAs, by far the most abundant fatty acid was C18:1 $\mathrm{n}-9$ cis9 (oleic acid), the percentage of which was not affected by the dietary treatments. The concentration of linoleic acid was greater $(P<0.05)$ in meat from bulls fed $\mathrm{C}$ compared with those fed EL. This result may be because of the higher concentration of this fatty acid in the control diet compared with the diet containing EL. As a consequence, since linoleic acid is the most abundant $n-6$ fatty acid, the total $n-6$ concentration was greater $(P<0.05)$ in meat from bulls that were fed $C$ than for those fed EL. Dietary EL increased $(P<0.01)$ the linolenic acid concentration of the meat relative to meat from bulls fed C (Corrazin et al., 2012; Ragni et al., 2014; Scerra et al., 2014), resulting in enhancement of the total n-3 fatty acid concentration as a consequence of feeding EL $(P<0.05)$. Ruminants bio-hydrogenate unsaturated fatty acids in the rumen (i.e., the unsaturated fatty acids are saturated) (Bickerstaffe et al., 1972; Harfoot \& Hazlewood, 1988; Bessa et al., 2000). This bio-hydrogenation then determines variations in the fatty acid composition of meat since some of the dietary PUFAs escape from the rumen and reach the intestinal lumen where they may be absorbed and then deposited as intramuscular fat.

Because FA ratios are important indicators for human health, it is noteworthy that no differences between the treatments were detected for the PUFA/SFA, in agreement with Vicenti et al. (2009). Although both dietary treatments provided meat with favourable characteristics for human health, since the $n-6 / n-3$ ratios recorded were less than the recommended maximum value of 4 , the $E L$ diet improved this ratio markedly by lowering it to $2.33(P<0.05)$. Tarricone et al. (2011) also reported that Podolian meat is 
characterised by favourable PUFA/SFA and $n-6 / n-3$ ratios. The $n-6 / n-3$ ratio represents an indicator that is used to evaluate the nutritional quality of food lipid fractions. Values above 4 are held responsible for the occurrence of coronary heart disease (CHD) and cancer (Department of Health, 1994; Enser, 2001). Furthermore, the n-6/n-3 ratio may differ widely within breed and depends on the production system (Enser et al., 1998; Wood et al., 2008).

Table 6 Fatty acid composition (\% total fatty acid methyl esters) of meat from the Longissimus lumborum muscle of Podolian young bulls

\begin{tabular}{|c|c|c|c|}
\hline & \multicolumn{2}{|c|}{ Diets } & \multirow{2}{*}{ SED $^{1}$} \\
\hline & Control & Extruded linseed & \\
\hline Total fatty acids (g/100 g muscle) & 2.22 & 2.65 & 0.253 \\
\hline C12:0 (lauric acid) & 0.07 & 0.06 & 0.018 \\
\hline C14:0 (myristic acid) & 2.50 & 2.76 & 0.575 \\
\hline C16:0 (palmitic acid) & 22.42 & 22.28 & 2.267 \\
\hline C18:0 (stearic acid) & 12.36 & 11.83 & 2.084 \\
\hline C20:0 (arachidic acid) & 0.33 & 0.40 & 0.136 \\
\hline Total SFA ${ }^{2}$ & 37.68 & 37.33 & 3.924 \\
\hline C14:1 (tetradecenoic acid) & 0.72 & 0.89 & 0.168 \\
\hline C16:1 c9 (palmitoleic acid) & 3.12 & 3.19 & 0.483 \\
\hline C17:1 c10 (heptadecenoic acid) & 0.65 & 0.61 & 0.132 \\
\hline C18:1 c7 (n-7; vaccenic acid) & 4.37 & 2.98 & 2.074 \\
\hline C18:1 c9 (n-9; oleic acid) & 39.75 & 40.30 & 3.615 \\
\hline C20:1 c11 (eicosenoic acid) & 0.03 & 0.06 & 0.074 \\
\hline Total MUFA ${ }^{3}$ & 48.64 & 48.03 & 3.676 \\
\hline C18:2 c9, 12 (n-6; linoleic acid) & $4.08^{\mathrm{a}}$ & $3.30^{b}$ & 1.327 \\
\hline C18:2 c9, t11 (n-6; rumenic acid) & 0.28 & 0.27 & 0.154 \\
\hline C18:3 c6, 9, 12 (n-6; y-Linolenic acid ) & 0.10 & 0.06 & 0.033 \\
\hline C20:2 c 11, 14 (n-6; eicosadienoic acid ) & 0.08 & 0.06 & 0.055 \\
\hline C20:3 c8, 11, 14 (n-6; dihomo-y-linolenic acid ) & 0.19 & 0.14 & 0.355 \\
\hline Total $n-6^{3}$ & $4.73^{\mathrm{a}}$ & $3.83^{b}$ & 0.351 \\
\hline C18:3 c9, 12, 15 (n-3; linolenic acid) & $0.20^{\mathrm{B}}$ & $0.45^{\mathrm{A}}$ & 0.072 \\
\hline C20:3 c11, 14, 17 (n-3; eicosatrienoic acid) & 0.77 & 0.80 & 0.882 \\
\hline $\mathrm{C} 20: 4$ c5, 8, t11, c14 (n-3) & 0.01 & 0.06 & 0.011 \\
\hline C20:5 c8, 11, 14, 17 (n-3; eicosapentaenoic acid-EPA) & 0.04 & 0.10 & 0.058 \\
\hline C22:5 c7, 10, 13, 16, 19 (n-3; docosapentaenoic acid-DPA) & 0.06 & 0.08 & 0.040 \\
\hline C22:6 c7, 10, 13, 16, 19 (n-3; docosahexaenoic acid-DHA) & 0.10 & 0.15 & 0.106 \\
\hline Total $n-3^{3}$ & $1.18^{\mathrm{b}}$ & $1.64^{\mathrm{a}}$ & 0.141 \\
\hline Total PUFA ${ }^{3}$ & 5.91 & 5.37 & 0.528 \\
\hline PUFA/SFA & 0.16 & 0.20 & 0.090 \\
\hline$n-6 / n-3$ & $4.00^{b}$ & $2.33^{\mathrm{a}}$ & 1.425 \\
\hline Atherogenic index & 0.77 & 0.85 & 0.114 \\
\hline Thrombogenic index & 1.82 & 1.80 & 0.067 \\
\hline \multicolumn{4}{|c|}{ 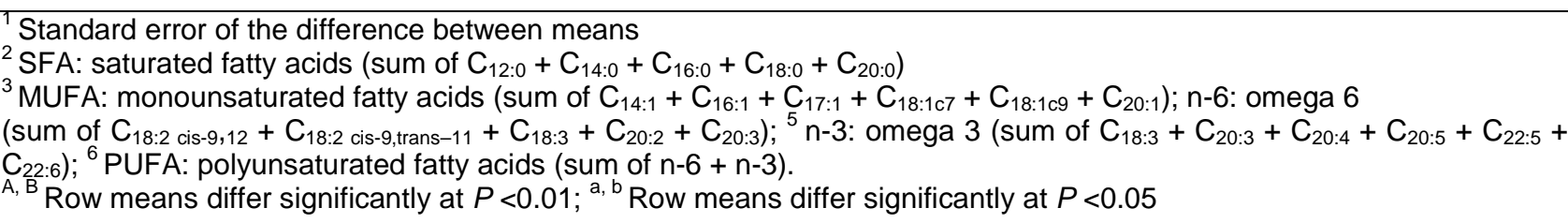 } \\
\hline
\end{tabular}


Similar to the findings of Vicenti et al. (2009), no dietary effect on the thrombogenic and atherogenic indices of meat from Podolian bulls was detected in this study. This was probably because of the lack of differences between treatments in the concentration of the saturated fatty acids C12:0 (lauric acid), C14:0 (myristic acid), C16:0 and C18:0, and total MUFAs, which contribute to the computation of these indices.

\section{Conclusion}

Dietary supplementation with 3\% EL in young Podolian bulls did not affect growth or carcass quality. However, it enhanced the fatty acid composition of the meat by improving the total amount of $n-3$ fatty acids, especially its linolenic acid content and the n-6/n-3 ratio. Therefore, EL feed contributed to improved healthfulness of beef from Podolia, an autochthonous breed that provides lean meat characterized by a beneficial fatty acid profile.

\section{Acknowledgements}

The authors would like to acknowledge Mr. Massimo Lacitignola and Dr. Nicolò De Vito for their technical assistance.

\section{Authors' Contributions}

ST and MR conceived and designed the study. ST performed the experimental work and laboratory analysis. MAC prepared and wrote the paper. ST and MAC carried out meat analysis. FG collaborated in animal management and in the collection of the performance data. AMC and AMF were involved in the analysis of the data, interpretation of the results, and in the constructive revision of the manuscript.

\section{Conflict of Interest Declaration}

The authors declare that they have no competing interests.

\section{References}

AOAC, 1995. Official methods of analysis. 16th edition. Association of Official Analytical Chemists, Inc., Arlington, Virginia, USA.

AOAC, 2004. Official methods of analysis. 18th edition. Association of Official Analytical Chemists, Inc., Arlington, Virginia, USA.

ASPA, 1996. Metodiche per la determinazione delle caratteristiche qualitative della carne (Procedures for meat quality evaluation). Scientific Association of Animal Production, Università di Perugia, Perugia, Italy (in Italian).

Bessa, R.J.B., Santos-Silva, J., Ribeiro, J.M.R., \& Portugal, A.V., 2000. Reticulo-rumen biohydrogenation and the enrichment of ruminant edible products with linoleic acid conjugated isomers. Liv. Prod. Sci. 63, 201-211.

Bickerstaffe, R., Noakes, D.E. \& Anmison, N.F., 1972. Quantitative aspects of fatty acid biohydrogenation, absorption and trans- isomers of octadecenoate and linoleate. Biochem. J. 30, 607-617.

Bragaglio, A., Napolitano, F., Pacelli, C., Pirlo, G., Sabia, E., Serrapica, F., Serrapica, M. \& Braghieri, A., 2018. Environmental impacts of Italian beef production: A comparison between different systems. J. Clean. Prod. 172, 4033-4043.

Braghieri, A., De Rosa, G., Spadetta, M., Girolami, A. \& Napolitano, F., 2009. Behaviour and meat quality of Podolian young bulls. Ital. J. Anim. Sci. 8(2), 598-600.

Christie, W.W., 1982. Lipid analysis-isolation, separation, identification and structural analysis of lipids. Pergamon, Oxford, pp. 270.

Colonna, M.A., Giannico, F., Coluccia, A., Di Bello, G., Vonghia, G. \& Jambrenghi, A.C., 2011. Dietary supplementation with extruded linseed and linseed oil in lamb feeding: productive performances and meat quality traits. Progr. Nutr. 13, 111-124.

Corrazin, M., Bovolenta, S., Sepulcri, A. \& Piasentier, E., 2012. Effect of whole linseed addition on meat production and quality of Italian Simmental and Holstein young bulls. Meat Sci. 90, 99-105.

Cosentino, C., D’Adamo, C., Naturali, S., Pecora, G., Paolino, R., Musto, M., Adducci, F. \& Freschi, P., 2018. Podolian cattle: Reproductive activity, milk and future prospects. Ital. J. Agron. 13 (982), 200-207.

Della Rosa, M.M., Pounzo, L.B. \& Pavan, E., 2018. Meat and fat quality traits of grazing steers supplemented with corn grain and increasing amounts of flaxseed. Meat Sci. 208, 51-54.

Department of Health, 1994. Nutritional Aspects of Cardiovascular Disease. Report of Health and Social Subject No. 46. HMSO, London.

Enser, M., 2001. The role of fats in human nutrition. In: Rossell B. (ed). Oils and fats. Volume 2. Animal carcass fats. Leatherhead Publishing, Leatherhead, Surrey, UK, 77-122.

Enser, M., Hallett, K.G., Hewett, B., Fursey, G.A.J., Wood, J.D. \& Harrington, G., 1998. Fatty acid content and composition of UK beef and lamb muscle in relation to production system and implications for human nutrition. Meat Sci. 49, 329-341.

Facciolongo, A.M., Lestingi, A., Colonna, M.A., Nicastro, F., De Marzo, D. \& Toteda, F., 2018. Effect of diet lipid source (linseed versus soybean) and gender on performance, meat quality and intramuscular fatty acid composition in fattening lambs. Small Rum. Res. 159, 11-17.

Folch, J., Lees, M. \& Sloan-Stanley, G.H., 1957. A simple method for the isolation and purification of total lipids from animal tissues. J. Biol. Chem. 226, 497-509. 
Giannico, F., Colonna, M.A., Coluccia, A., Crocco, D., Vonghia, G., Cocca, C. \& Jambrenghi, A.C., 2009. Extruded linseed and linseed oil as alternative to soybean meal and soybean oil in diets for fattening lambs. Ital. J. Anim. Sci. 8, 495-497.

Gonthier, C., Mustafa, A.F., Berthiaume, R., Petit, H.V. \& Ouellet, D.R., 2004. Feeding micronized and extruded flaxseed to dairy cows: Effects on digestion and ruminal biohydrogenation of long-chain fatty acids. Can. J. Anim. Sci. 84, 705-711.

Harfoot, C.G. \& Hazlewood, G.P., 1988. Lipid metabolism in the rumen. In: P.N. Hobson (ed.). The rumen microbial ecosystem. Elsevier Applied Science, London, 285-322.

INRA, 1988. Alimentation des bovines, ovins et caprins. INRA, Paris, France (in French).

INRA, 1989. Ruminant nutrition. Recommended allowances and feed tables. INRA, Paris (in French).

Juarez, M., Dugan, M., Aldai, N., Basarab, J.A., Baron, V.S., McAllister, T.A. \& Aalhus. J.L., 2012. Beef quality attributes as effected by increasing the intramuscular levels of vitamin $E$ and omega-3 fatty acids. Meat Sci. 90, 764-769.

Lunn, J. \& Theobald, H.E., 2006. The health effects of dietary unsaturated fatty acids. Nutr. Bull. 31, 178-224.

Mapiye, C., Aalhus, J.L., Turner, T.D., Rolland, D.C., Basarab, J.A., ..., Dugan, M.E.R., 2013. Effects of feeding flaxseed or sunflower-seed in high-forage diets on beef production, quality and fatty acid composition. Meat Sci. 95, 98109.

Marino, R., Albenzio, M., Girolami, A., Muscio, A., Sevi, A. \& Braghieri, A., 2006. Effect of forage to concentrate ratio on growth performance and on carcass and meat quality of Podolian young bulls. Meat Sci., 72, 415-424.

McAfee, A.J., McSorley, E.M., Cuskelly, G.J., Moss, B.W., Wallace, J.M.W., Bonham, M.P. \& Fearon, A.M., 2010. Red meat consumption: an overview of the risks and benefits. Meat Sci. 84, 1-13.

Mustafa, A.F., Gonthier, C., \& Ouellet, D.R., 2003. Effects of extrusion of flaxseed on ruminal and post ruminal nutrient digestibilities. Arch. Anim. Nutr. 57, 455-463.

Raes, K., Haak, L., Balcaen, A., Clayes, E., Demeyer, D. \& De Smet, S., 2004. Effect of linseed feeding at similar linoleic acid levels on the fatty acid composition of double-muscled Belgian Blue young bulls. Meat Sci. 66, 307-315.

Ragni, M., Colonna, M.A., Lestingi, A., Tarricone, S., Giannico, F., Marsico, G. \& Facciolongo, A.M., 2018. Effects of protein sources on performance, carcass composition, blood parameters and meat quality in Charolais heifers. S. Afr. J. Anim. Sci. 48, 683-694.

Ragni, M., Toteda, F., Tufarelli, V., Laudadio, V., Facciolongo, A., Dipalo, F. \& Vicenti, A., 2014. Feeding of extruded flaxseed (Linum usitatissimum L.) and pasture in Podolica young bulls: Effects on growth traits, meat quality and fatty acid composition. Pak. J. Zool. 46, 1101-1109.

Razminowicz, R.H., Kreuzer, M., Leuenberger, H. \& Scheeder, M.R.I., 2007. Efficiency of extruded linseed for the finishing of grass-fed steers to counteract a decline of omega-3 fatty acids in the beef. Liv. Sci., 114, 150-163.

Rotondi, P., Colonna, M.A., Marsico, G., Giannico, F., Ragni, M. \& Facciolongo, A.M., 2018. Dietary supplementation with oregano and linseed in Garganica suckling kids: Effects on growth performances and meat quality. Pak. J. .Zool. 50, 1421-1433.

Salter, A.M., 2013. Dietary fatty acids and cardiovascular disease. Animal 7, 163-171.

SAS, 2000. Statistical Analysis System user's guide. SAS Institute Inc., Raleigh, North Carolina, USA.

Scerra, M., Foti, F., Cilione, C., Chies, L., Scerra, V. \& Caparra, P., 2014. Influence of stall finishing of Podolian young bulls raised on pasture on fatty acid composition and oxidative status of meat. Ital. J. Anim. Sci. 13, 857-863.

Scollan, N.D., Dannenberger, D., Nuernberg, K., Richardson, I., MacKintosh, S., Hocquette, J.F. \& Moloney, A.P., 2014. Enhancing the nutritional and health value of beef lipids and their relationship with meat quality. Meat Sci. 97 , 384-394.

Šicklep, M. \& Čandek-Potokar, M., 2007. Pork color measurement as affected by bloom time and measurement location. J. Muscle Foods 18, 78-87.

Simopoulos, A.P., 2004. Omega-6/omega-3 essential fatty acid ratio and chronic diseases. Food Rev. Int. $20,77-90$.

Tarricone, S., Karatosidi, D., Pinto, F., Cagnetta, P., Vicenti, A., Marsico, G. \& Colangelo, D., 2011. Composizione acidica del grasso delle carni di vitelloni Podolici di 14 e 18 mesi di età. Progr. Nutr. 13, 135-140 (in Italian, abstract in English).

Toteda, F., Facciolongo, A., Ragni, M. \& Vicenti, A., 2011. Effect of suckling type and PUFA use on productive performances, quanti-qualitative characteristics of meat and fatty acid profile in lamb. Prog. Nutr. 13, 125-134.

Ulbricht, T.L. \& Southgate, D.A.T., 1991. Coronary heart disease: Seven dietary factors. The Lancet 338, 985-922.

Utama, D.T., Lee, S.G., Baek, K.H., Chung, W.S., Chung, I.A., Kim, D.I., Kim, G.Y. \& Lee, S.K., 2018. Blood profile and meat quality of Holstein-Friesian steers finished on total mixed ration of flaxseed oil-supplemented pellet mixed with reed canary haylage. Animal 12, 426-433.

Vicenti, A., Toteda, F., Di Turi, L., Cocca, C., Perrucci, M., Melodia, L. \& Ragni, M., 2009. Use of sweet lupin (Lupinus albus L. var. Multitalia) in feeding for Podolian young bulls and influence on productive performances and meat quality traits. Meat Sci. 82, 247-251.

Wood, J.D., Enser, M., Fisher, A.V., Nute, G.R., Sheard, P.R., ..., Whittington, F.M., 2008. Fat deposition, fatty acid composition and meat quality: A review. Meat Sci. 78, 343-358.

World Health Organisation, 2003. Diet, nutrition and the prevention of chronic diseases. Report of the joint WHO/FAO Expert Consultation. Volume 916. WHO, Geneva. 